\title{
Efektivitas Implementasi Strategi Enjoyable Learning Berbantuan Media Audio Visual Terhadap Hasil Belajar Bahasa Inggris Permulaan Peserta Didik Sekolah Dasar
}

\author{
*Gede Wira Bayu'1, Luh Gede Eka Wahyuni² \\ ${ }_{1}$ Pendidikan Guru Sekolah Dasar FIP, Universitas Pendidikan Ganesha, Indonesia \\ ${ }^{2} J u r u s a n$ Pendidikan Bahasa Inggris FBS, Universitas Pendidikan Ganesha, Indonesia
}

\author{
A R T I C L E I N F O \\ Article history: \\ Received 10 May 2019 \\ Received in revised form \\ 10 June 2019 \\ Accepted 15 July 2019 \\ Available online 29 August \\ 2019 \\ Kata Kunci: \\ enjoyable learning, audio \\ visual. \\ Keywords: \\ enjoyable learning, audio \\ visual.
}

\begin{abstract}
A B S T R A K
Penelitian didasari atas rendahnya hasil belajar belajar Bahasa Inggris disekolah dasar khususnya setelah implementasi kurikulum 2013 dimana waktu pembelajaran bahasa inggris jauh berkurang dari 4 jam pelajaran seminggu pada Kurikulum Tingkat Satuan Pendidikan (KTSP) menjadi hanya 2 jam pelajaran seminggu pada kurikulum 2013. penelitian pre-eksperimen One Group Pretest-Posttest Design. Subjek pada penelitian ini adalah siswa kelas 2 di 8 sekolah dasar yang baru menerapkan kurikulum 2013 di kecamatan Buleleng. Data pada penelitian ini didapatkan dengan metode wawancara dan catatan lapangan. Dengan teknik random sampling subjek penelitian ini dipilih yaitu siswa kelas 2 di SD sejumlah 27 siswa sebagai kelompok kontrol, dan 25 siswa sebagai kelompok eksperimen. Berdasarkan hasil perhitungan nilai thitung sebesar 5,34. Rata-rata kelompok eksperimen sebesar 20,86 dan kelompok kontrol sebesar 15,18. Hal ini berarti ratarata kelompok eksperimen > rata-rata kelompok kontrol. Dengan demikian strategi strategi Enjoyable Learning berbantuan media audio
\end{abstract} visual berpengaruh signifikan terhadap hasil belajar Bahasa Inggris pada siswa kelas II SD Penerapan Kurikulum 2013.

\begin{abstract}
A B S T R A C T
This research based on the low learning outcomes of English language learning in elementary schools especially after the implementation of the 2013 curriculum where the time of learning English is much reduced from 4 hours a week in the Education Unit Level Curriculum (KTSP) to only 2 hours a week in the 2013 curriculum. It used Pre-experimental research One Group Pretest-Posttest Design. The subjects in this study were second grade students in 8 elementary schools who had just implemented the 2013 curriculum in the 2018/2019 academic year at Buleleng sub-district. The data obtained by interview methods and field notes. With the random sampling technique, the subjects of this study were selected, second grade students of SD N 5 Banyuning, amount to 27 students as a control group, and second grade students in SD N 2 Banjar Tegal, amount to 25 students as the experimental group. Based on the results of the calculation of the tcount of 5.34 from the average, it was known that the experimental group was 20.86 and the control group was 15.18. It means experiment> control group. Thus, the Enjoyable Learning strategy assisted by audio visual media has a significant effect on the learning outcomes of English in second grade students in 2013 Curriculum Application in the District of Buleleng, Buleleng Regency, 2018/2019 academic year.
\end{abstract}

\section{Pendahuluan}

Menurut Undang-Undang Sistem Pendidikan Nasional No.20 Tahun 2003 pasal 1 butir 1, pendidikan adalah: "usaha sadar dan terencana untuk mewujudkan suasana belajar dan proses pembelajaran agar peserta didik secara aktif mengembangkan potensi dirinya untuk memiliki kekuatan

Copyright (c) Universitas Pendidikan Ganesha. All rights reserved. 
spiritual keagamaan, pengendalian diri, kepribadian, kecerdasaan, akhlak mulia, serta keterampilan yang diperlukan dirinya, masyarakat, bangsa dan Negara." Pendidikan nasional bertujuan: "untuk mengembangkan potensi peserta didik agar menjadi manusia yang beriman dan bertakwa kepada Tuhan Yang Maha Esa, berakhlak mulia, cakap, kreatif, mandiri, dan menjadi waarga Negara yang demokratis serta bertanggung jawab" (Depdiknas, 2007).

Proses pembelajaran pada satuan pendidikan diselenggarakan secara interaktif, inspiratif, menyenangkan, menantang, memotivasi peserta didik untuk berpartisipasi aktif, memberikan ruang gerak yang cukup bagi prakarsa, kreativitas dan kemandirian sesuai dengan bakat, minat dan perkembangan fisik, serta psikologi peserta didik". Rancangan pembelajaran yang inovatif tentu membutuhkan peran guru dalam menciptakan pola pembelajaran. Sebagaimana yang terjadi saat ini tantangan yang dihadapi dalam proses pembelajaran PAI adalah bagaimana mengimplementasikan PAI bukan hanya mengajarkan pengetahuan tentang agama saja melainkan bagaimana seorang guru mampu mengarahkan dan membentuk karakter peserta didik agar memiliki kualitas keimanan, ketakwaan dan akhlak mulia (Layyinah, 2017).

Pendidikan bukanlah proses yang diorganisasi secara teratur, terencana, dan menggunakan metode-metode yang dipelajari serta berdasarkan aturan-aturan yang telah disepakati mekanisme penyelenggaraan oleh suatu komunitas suatu masyarakat (Negara), melainkan lebih merupakan bagian dari kehidupan yang memang telah berjalan sejak manusia itu ada.Pendidikan bisa dianggap sebagai proses yang terjadi secara sengaja, direncanakan, didesain, dan diorganisasi berdasarkan aturan yang berlaku terutama perundang-undangan yang kesepakatan masyarakat.Pendidikan sebagai sebuah kegiatan dan proses aktivitas yang disengaja merupakan gejala masyarakat ketika sudah mulai disadari pentingnya upaya untuk membentuk, mengarahkan, dan mengatur manusia sebagaimana dicita-citakan masyarakat $(\mathrm{N}, 2005)$.

Kata "media" berasal dari bahasa Latin "medium" yang berarti "perantara" atau "pengantar". Lebih lanjut, media merupakan sarana penyalur pesan atau informasi belajar yang hendak disampaikan oleh sumber pesan kepada sasaran atau penerima pesan tersebut. Penggunaan media pengajaran dapat membantu pencapaian keberhasilan belajar. Ditegaskan oleh Danim bahwa hasil penelitian telah banyak membuktikan efektivitas penggunaan alat bantu atau media dalam proses belajar-mengajar di kelas, terutama dalam hal peningkatan prestasi siswa. Terbatasnya media yang dipergunakan dalam kelas diduga merupakan salah satu penyebab lemahnya mutu belajar siswa. Dengan demikian penggunaan media dalam pengajaran di kelas merupakan sebuah kebutuhan yang tidak dapat diabaikan. Hal ini dapat dipahami mengingat proses belajar yang dialami siswa tertumpu pada berbagai kegiatan menambah ilmu dan wawasan untuk bekal hidup di masa sekarang dan masa akan datang. Salah satu upaya yang harus ditempuh adalah bagaimana menciptakan situasi belajar yang memungkinkan terjadinya proses pengalaman belajar pada diri siswa dengan menggerakkan segala sumber belajar dan cara belajar yang efektif dan efisien. Dalam hal ini, media pengajaran merupakan salah satu pendukung yang efektif dalam membantu terjadinya proses belajar. Pada proses pembelajaran, media pengajaran merupakan wadah dan penyalur pesan dari sumber pesan, dalam hal ini guru, kepada penerima pesan, dalam hal ini siswa. Dalam batasan yang lebih luas, Yusufhadi Miarso memberikan batasan media pengajaran sebagai segala sesuatu yang dapat digunakan untuk merangsang pikiran, perasaan, perhatian, dan kemauan siswa sehingga mendorong terjadinya proses belajar pada diri siswa.3 Apabila dilihat dari manfaatnya Ely dalam Danim menyebutkan manfaat media dalam pengajaran adalah sebagai berikut: (a) Meningkatkan mutu pendidikan dengan cara meningkatkan kecepatan belajar (rate of learning), (b) Memberi kemungkinan pendidikan yang sifatnya lebih individual, (c) Memberi dasar pengajaran yang lebih ilmiah, (d) Pengajaran dapat dilakukan secara mantap, (e) Meningkatkan terwujudnya kedekatan belajar (immediacy learning), dan (f) Memberikan penyajian pendidikan lebih luas (Mahnun, 2012).

Media dalam pembelajaran berfungsi memperjelas pesan yang disampaikan guru. Media juga berfungsi sebagai alat bantu mengajar (Ahmad, Rivai dan Sujana, 2011). Media memudahkan siswa belajar, memberikan pengalaman konkrit, menarik perhatian, mengaktifkan indera siswa, dan membangkitkan dunia teori dengan realitanya. Namun pada kegiatan belajar mengajar, guru tidak selamanya dapat membawa siswa pada objek yang sebenarnya terjadi ataupun sebaliknya, maka diperlukan media untuk membantu guru dalam pembelajaran. Media pembelajaran berfungsi untuk menghadirkan objek yang tidak dapat dilihat siswa secara langsung atau obyek yang terlalu mikro untuk dapat dilihat langsung, misalnya memperbesar benda yang kecil, menyajikan peristiwa yang letaknya jauh, kompleks, rumit, yang berlangsung dengan sangat cepat atau lambat, menjadi lebih sistematik dan sederhana (Susarno, 2010). Penggunaan media pembelajaran harus bervariasi, menarik perhatian, lebih menyenangkan, dapat memberikan pengalaman belajar sehingga peserta didik dapat menangkap materi pelajaran dengan mudah. Jenis-jenis media yang dapat digunakan dalam pembelajaran adalah media grafis (gambar, foto, bagan, poster, dan lain-lain), media tiga dimensi (model kerja, mock up, diorama, dan 
lain-lain), media proyeksi (slide, film, OHP, dan lain-lain), serta penggunaan lingkungan sebagai media pembelajaran (Primasari \& Herlanti, 2015).

(Agus Suprijono, 2014), hasil belajar adalah polapola perbuatan, nilai-nilai, pengertian-pengertian, sikapsikap, apresiasi dan keterampilan. Selanjutnya (A, 2012) mengemukakan bahwa hasil belajar yang menjadi objek penilaian kelas berupa kemampuan-kemampuan baru yang diperoleh siswa setelah mereka mengikuti proses belajar-mengajar tentang mata pelajaran tertentu. Dalam sistem pendidikan nasional rumusan tujuan pendidikan mengacu pada klasifikasi hasil belajar dari Bloom yang secara garis besar yaitu aspek kognitif, aspek afektif dan aspek psikomotor (Ahmadi, Abu dan Supriyono, 2013).

Kemampuan berbahasa inggris merupakan gabungan ketrampilan membaca/reading, menulis/writing, mendengarkan/listening, dan berbicara/speaking. Dalam pembelajaran bahasa Inggris di SD, keempat ketrampilan tersebut diajarkan untuk dapat saling mendukung satu sama lainnya. Pembelajaran keterampilan mendengarkan dimulai dengan membedakan bunyi dengan pasangan kata. Pembelajaran keterampilan membaca dimaksudkan untuk memahami dam memperoleh informasi dari wacana tulisan. Ahli lain (Morrow) mengembangkan tujuan ini adalan untuk tujuan kognitif, referensial, maupun afektif dalam mendapatkan kenikmatan membaca. Pembelajaran keterampilan berbicara dimaksudkan agar siswa mampu menyampaikan informasi secara sosial dan dapat diterima oleh oleh penutur dan pendengar. Kegiatan komunikasi lisan dilakukan secara alami yang sesungguhnya, artinya komuikasi yang dilakukan telah mengandung kesenjangan informasi. Pembelajaran keterampilan menulis atau mengarang. Maksud dari pembelajaran ini adalah untuk mengungkapkan pikiran dan perasaan dalam bahasa.

Keterampilan membaca dan menulis harus segera dikuasai oleh para siswa di SD karena ketrampilan ini secara langsung berkaitan dengan seluruh proses belajar siswa di SD. Keberhasilan belajar siswa dalam mengikuti proses kegiatan belajar-mengajar di sekolah sangat ditentukan oleh penguasaan kemampuan membaca dan menulis mereka. Siswa yang tidak mampu membaca dan menulis dengan baik akan mengalami kesulitan dalam mengikuti kegiatan pembelajaran untuk semua mata pelajaran. Siswa akan mengalami kesulitan dalam menangkap dan memahami informasi yang disajikan dalam berbagai buku pelajaran, buku-buku bahan penunjang dan sumber-sumber belajar tertulis yang lain. Selain itu siswa akan kesulitan dalam menuangkan pikirannya tentang pembelajaran. Akibatnya, kemajuan belajarnya juga lamban jika dibandingkan dengan teman-temannya yang tidak mengalami kesulitan dalam membaca dan menulis.

Kenyataan menunjukkan bahwa banyak siswa yang tidak berminat dalam belajar bahasa inggris. Hal ini terpantau dari aktivitas belajar mereka dikelas. Kebanyakan siswa tidak menaruh minat pada pelajaran. Siswa lebih banyak bermain dengan teman serta menunjukkan perhatian yang tidak terfokus pada pelajaran. Metode yang digunakan oleh guru yang hanya bersifat ceramah, menyebabkan keterlibatan siswa dalam pembelajaran sangat minim. Sehingga kesempatan siswa untuk mengembangkan dan melatih pengetahuan berbahasa inggris mereka selama pembelajaran sangat sedikit. Hal ini akan membawa konsekuensi, siswa hanya berusaha menghafal cacatan yang diberikan oleh guru, sehingga kemampuan daya nalar dan keterampilan-keterampilan berbahasa siswa kurang mendapat sentuhan.

Pola interaksi yang terjadi selama pembelajaran bersifat satu arah, yaitu hanya dari guru kepada siswa. Kondisi ini, cenderung membuat siswa menjadi pasif, karena mereka hanya menerima apa yang disampaikan oleh guru, dan tidak diberikan kesempatan untuk mengungkapkan dan mengembangkan pengetahuannya selama pembelajaran. Jadi tidak ada hubungan timbal balik antara guru dan siswa. Akibatnya pengetahuan dan keterampilan siswa dalam belajar tidak berkembang. Demikian juga halnya, pada saat guru menutup pembelajaran yang langsung mengakhiri pembelajarannya tanpa memberikan umpan balik atau evaluasi terhadap unjuk kerja siswa selama pembelajaran. Hal itu menyebabkan siswa merasa selalu benar dan baik mengenai apa yang mereka tampilkan selama pembelajaran berlangsung, sehingga kondisi iklim kelas bersifat monoton, yang akhirnya menyebabkan kegairahan dan semangat siswa dalam belajar menjadi rendah. Pembelajaran yang demikian, akhirnya hanya akan membawa konsekuensi yang tidak baik bagi hasil belajar siswa dan minat siswa terhadap pelajaran bahasa Inggris yang cenderung jadi "momok" yang menakutkan bagi siswa.

Berdasarkan uraian kendala-kendala yang terkait dengan pelaksanaan pembelajaran bahasa inggris sebagaimana yang diuraikan, maka perlu adanya modifikasi pembelajaran yang mampu menjembatani semua kepentingan, termasuk pemberian kesempatan yang optimal pada siswa untuk belajar, dan pengembangan kemampuan dan keterampilan berbahasa inggris siswa dalam pembelajaran. Setelah dilakukan refleksi terhadap profil pembelajaran bahasa inggris sebagaimana yang berhasil direkam pada studi pendahuluan dan memang hal tersebut telah menyadari oleh guru. Namun diakui oleh peneliti sendiri, ada hambatan bagi mereka dalam memilih strategi yang mampu menjempatani kelemahankelemahan tersebut, khususnya yang sesuai dengan karakteristik bahasa inggris di sekolah dasar atau 
English for Children, terutama dalam misinya sebagai menunjang kemampuan perserta didik dalam berkomunikasi dan mengenal budaya internasional sejak dini.

Strategi enjoyable learning berbantuan media audio visual diharapkan dapat mengatasi masalah yang dihadapi disekolah dasar yaitu mampu meningkatkan minat dan hasil belajar bahasa inggris. Startegi enjoyable learning diimplementasikan guna menciptakan suasana pembelajaran yang menyenangkan sehingga minat peserta didik dalam belajar bahasa inggris meningkat dan dengan bantuan media audio visual mampu memberikan pemahaman yang lebih baik sehingga meningkatkan hasil belajar bahasalinggris.

Penelitian ini diarahkan untuk mengetahui efektivitas implementasi strategi enjoyable learning berbantuan media audio visual pada pelajaran membaca dan menulis permulaan pada mata pelajaran Bahasa Inggris.

\section{Metode}

Penelitian ini merupakan penelitian ekperimen semu, karena belum memenuhi persyaratan rancangan penelitian eksperimen sesungguhnya (true experiment). Penelitian eksperimen semu tidak bisa memberikan kontrol perlakuan sepenuhnya atau tidak semua variabel dan kondisi eksperimen dapat diatur serta dikontrol secara ketat. Pada penelitian eksperimen semu, random hanya dilakukan pada penentuan kelompok eksperimen dan kontrol.

Rancangan penelitian yang digunakan adalah nonequivalent post-test only control group desain, yaitu hanya menggunakan post-test yang dilakukan pada akhir penelitian. Rancangan penelitian ini disajikan pada Tabel 1.

Tabel 1. Rancangan Penelitian Nonequivalent Post-test Only Control Group Desain

\begin{tabular}{|c|c|c|}
\hline Kelas & Perlakuan & Post-test \\
\hline Eksperimen & $\mathrm{X}_{1}$ & $\mathrm{O}_{1}$ \\
\hline Kontrol & - & $\mathrm{O}_{2}$ \\
\hline
\end{tabular}

Keterangan :

$\mathrm{O}_{1} \quad$ : observasi post-test kelompok eksperimen setelah diberikan perlakuan.

$\mathrm{O}_{2} \quad$ : observasi post-test kelompok kontrol setelah diberikan perlakuan.

$\mathrm{X}_{1} \quad$ : perlakuan yang diberikan pada kelas eksperimen dengan Strategi enjoyable learning berbantuan media audio visual

: tidak ada perlakukan khusus.

Dalam penelitian ini, perlakuan diberikan pada kelas eksperimen dengan menggunakan strategi enjoyable learning berbantuan media audio visual. Sedangkan pada kelas kontrol tidak berikan perlakuan khsusus artinya tidak digunakan strategi tertentu, pembelajaran disesuaikan dengan pembelajaran yang biasa dilakukan guru di sekolah tersebut seperti sebelum dilakukan penelitian. Setelah perlakuan baik kelas kontrol maupun kelas eksperimen dilaksanakan maka kedua kelompok tersebut diberikan post-test untuk mengetahui hasil belajar masing-masing kelompok.

Populasi penelitian ini adalah seluruh peserta didik sekolah dasar yang baru menerapkan kurikulum 2013 di kabupaten Buleleng tahun pelajaran 2018/2019.

Berdasarkan karakteristik populasi maka penentuan sampel pada penelitian ini dilakukan dengan teknik random sampling. Sampel diambil berdasarkan kelas bukan individu, setiap anggota populasi atau bagian dari populasi tersebut mempunyai kesempatan yang sama untuk dipilih sebagai sampel. Dari 8 sekolah populasi dipilih dua sekolah sebagai sampel penelitian. Dan pilihannya adalah Siswa Kelas II di SD N 2 Banjar Tegal sebagai kelompok eksperimen yang diberikan perlakukan strategi enjoyable learning berbantuan media audio visual dan siswa kelas II di SD N 5 Banyuning sebagai kelompok kontrol yang tidak diberikan perlakuan khusus.

Prosedur dari pelaksanaan eksperimen ini meliputi tahapan-tahapan penelitian dan perlakuan penelitian baik pada kelas kontrol dan kelas eksperimen. Proses pemberian perlakukan untuk kelompok eksperimen dilakukan sebanyak delapan kali pertemuan dengan 5 kali pembelajaran (masing-masing pertemuan 2-3 x 35 menit) dan 1 kali post-test. Setiap kelompok mendapatkan perlakuan pengajaran sesuai dengan isi dan waktu pelaksanaan pengajaran yang sama sesuai dengan jadwal di sekolah masingmasing. Prosedur penelitian yang dilaksanakan pada penelitian ini adalah sebagai berikut.

1) Menentukan sampel berupa kelas dari populasi yang tersedia. Dilanjutkan dengan dilakukan pengundian untuk menentukan kelas eksperimen dan kelas kontrol. 
2) Melakukan pre-test terhadap kemampuan permulaan bahasa inggris di kelas eksperiman dan kelas kontrol,

3) Melakukan wawancara terhadap minat siswa terhadap pelajaran bahasa inggris baik dikelas eksperimen maupun dikelas kontrol.

4) Menyusun perangkat pembelajaran yang akan dibelajarkan selama proses belajar mengajar dengan menerapkan strategi enjoyable learning berbantuan media audio visual. Disamping itu, peneliti juga menyiapkan instrumen penelitian, yaitu: (1) quisioner minat belajar bahasa inggris dan (2) tes hasil belajar bahasa inggris.

5) Memberikan perlakuan pembelajaran yang diteliti. Pembelajaran dengan strategi enjoyable learning berbantuan media audio visual pada kelas eksperimen dan tidak memberikan perlakuan khusus pada kelas kontrol.

6) Mengadakan post-test pada kelas eksperimen dan kelas kontrol.

7) Melaksanakan analisis data hasil belajar sesuai data yang diperoleh.

8) Menyusun laporan penelitian.

Untuk menganalisis data dalam penelitian ini digunakan dua jenis statistik, yaitu statistik deskriptif dan statistik inferensial. Statistik deskriptif dimaksudkan untuk menggambarkan keadaan populasi dalam bentuk rata-rata, median, modus, standar deviasi, skewness dan kurtosis. Selanjutnya untuk menentukan tingkat hasil belajar terhadap suatu materi digunakan kriteria tinggi, sedang, dan rendah. Sedangkan untuk statistik inferensial dimaksudkan untuk menguji hipotesis penelitian.

Model ini tidak mempertimbangkan adanya randomisasi pengambilan kelompok dan tidak memperhitungkan skor pre-est yang diperoleh, juga tidak menggunakan pengontrolan terhadap variabel. Uji hipotesis menggunakan uji t. t-test digunakan untuk menguji perbedaan dua buah rerata nilai dua variabel. Teknik tersebut mempunyai keterbatasan tertentu yakni tidak dapat digunakan untuk membedakan rerata yang lebih dari dua nilai. Untuk menguji hipotesis penelitian dilakukan dengan tahapan uji normalitas, uji homogenitas dan uji hipotesis.

1. Uji Normalitas

Uji normalitas data dimaksudkan untuk mengetahui populasi berdistribusi normal atau tidak. Prasyarat yang harus terpenuhi untuk sampai uji $t$ adalah populasi data harus berdistribusi normal.

2. Uji Homogenitas

Uji homogenitas data dimaksudkan untuk mengetahui apakah varians data kedua kelompok yang diteliti mempunyai varians yang homogen atau tidak. Uji homogenitas varians dilakukan dengan uji-F.

3. Uji Hipotesis

Uji hipotesis data yang dapat dilakukan dengan uji t. Uji t pada dasarnya adalah untuk uji hipotesis nihil tentang perbedaan Mean dari dua sampel atau dua variabel. Masing - masing variabel tersebut berskala internal/rasio dan adanya linieritas dan normalitas. Berikut beberapa rumus Uji $t$ dan penggunaannya.

\section{Hasil dan Pembahasan}

Tabel 2. Distribusi Frekuensi Data Hasil Belajar Bahasa Inggris Siswa Kelas Eksperimen

\begin{tabular}{|c|c|c|c|c|c|c|}
\hline No & Interval & $\begin{array}{c}\text { Batas } \\
\text { Bawah }\end{array}$ & $\begin{array}{c}\text { Titik } \\
\text { Tengah }(\mathrm{X})\end{array}$ & $\begin{array}{l}\text { Frekuensi } \\
\text { Absolut (f) }\end{array}$ & $\begin{array}{l}\text { Frekuensi } \\
\text { Kumulatif }\end{array}$ & $f(X)$ \\
\hline 1 & $13-15$ & 12,5 & 14 & 2 & 2 & 28 \\
\hline 2 & $16-18$ & 15,5 & 17 & 4 & 6 & 68 \\
\hline 3 & $19-21$ & 18,5 & 20 & 6 & 11 & 100 \\
\hline 4 & $22-24$ & 21,5 & 23 & 9 & 20 & 207 \\
\hline \multirow[t]{7}{*}{5} & $25-27$ & 24,5 & 26 & 3 & 22 & 52 \\
\hline & & $\sum$ & & 25 & & 455 \\
\hline & & Mean & & & 20,88 & \\
\hline & & Median & & & 21,52 & \\
\hline & & Modus & & & 22,60 & \\
\hline & & Varians & & & 11.99 & \\
\hline & & dar Deviasi & & & 3,48 & \\
\hline
\end{tabular}

Jika skor Mean (M), Median (Md), dan Modus (Mo) digunakan dalam grafik, maka kurva sebaran kelompok siswa yang dibelajarkan menggunakan strategi Enjoyable Learning berbantuan Media Audio 
Visual merupakan kurva juling negatif karena $\mathrm{Mo}>\mathrm{Md}>\mathrm{M}(22,60>21,52>20,88)$. Ini menunjukkan sebagian besar skor cenderung tinggi. Berdasarkan pada tabel pedoman konversi kecenderungan data hasil belajar Bahasa Inggris, skor rata-rata kelompok eksperimen berada pada kategori sangat tinggi yaitu sebesar 20,88 (terletak antara 18,75 $\leq \bar{X} \leq 25$ ).

Tabel 3. Distribusi Frekuensi Hasil Post-test Siswa Kelompok Kontrol

\begin{tabular}{|c|c|c|c|c|c|c|}
\hline No & Interval & $\begin{array}{l}\text { Batas } \\
\text { Bawah }\end{array}$ & $\begin{array}{c}\text { Titik } \\
\text { Tengah }(X)\end{array}$ & $\begin{array}{l}\text { Frekuensi } \\
\text { Absolut (f) }\end{array}$ & $\begin{array}{l}\text { Frekuensi } \\
\text { Kumulatif }\end{array}$ & $f(X)$ \\
\hline 1 & $9-11$ & 8,5 & 10 & 4 & 4 & 40 \\
\hline 2 & $12-14$ & 11,5 & 13 & 8 & 12 & 104 \\
\hline 3 & $15-17$ & 14,5 & 14 & 4 & 15 & 42 \\
\hline 4 & $18-20$ & 17,5 & 19 & 7 & 21 & 114 \\
\hline \multirow[t]{7}{*}{5} & $21-23$ & 20,5 & 22 & 4 & 24 & 66 \\
\hline & & $\sum$ & & 27 & & 366 \\
\hline & & Mean & & & 15,27 & \\
\hline & & Median & & & 14,56 & \\
\hline & & Modus & & & 12,84 & \\
\hline & & Varians & & & 14,22 & \\
\hline & & dar Deviasi & & & 3,78 & \\
\hline
\end{tabular}

Jika skor Mean (M), Median (Md), dan Modus (Mo) digunakan dalam grafik, maka kurva sebaran kelompok siswa yang dibelajarkan tidak menggunakan strategi CIRC berbantuan media gambar merupakan kurva juling positif, karena $\mathrm{Mo}<\mathrm{Md}<\mathrm{M}(12,84<14,56<15,27)$. Ini menunjukkan sebagian besar skor cenderung rendah. Berdasarkan pada tabel pedoman konversi kecenderungan data hasil keterampilan membaca intensif, skor rata-rata kelompok kontrol berada pada kategori tinggi yaitu sebesar 15,27 (terletak antara 14,58 $\leq \bar{X} \leq 18,75$ ).

Berdasarkan uraian mengenai hasil post-test hasil belajar Bahasa Inggris siswa pada kelompok eksperimen dan hasil post-test kelompok kontrol di atas, terlihat adanya perbedaan hasil belajar Bahasa Inggris antara kelompok eksperimen (kelompok siswa yang dibelajarkan menggunakan model Enjoyable Learning berbantuan media audio visual) dan kelompok kontrol (kelompok siswa yang dibelajarkan tidak menggunakan model Enjoyable Learning berbantuan media audio visual). Dapat dilihat pada tabel 5.3.

Tabel 4. Statistik Deskriptif Hasil Penelitian

\begin{tabular}{cccc}
\hline Statistik & Kelompok Eksperimen & Kelompok Kontrol \\
Banyak Sampel & 25 & 27 \\
Mean & 20,88 & 15,27 \\
Median & 21,52 & 14,56 \\
Modus & 22,60 & 12,84 \\
Varians & 11.99 & 14,22 \\
Standar Deviasi & 3,48 & 3,78 \\
\hline
\end{tabular}

Tabel 5. Data Rekapitulasi hasil Perhitungan Uji Hipotesis

\begin{tabular}{ccccccc}
\hline Kelompok & $\mathrm{N}$ & $\mathrm{Db}$ & Mean & Varians & thitung & tabel \\
\hline Eksperimen & 25 & 44 & 20,86 & 11,99 & 5,34 & 2,023 \\
Kontrol & 27 & & 15,27 & 14,25 & & \\
\hline
\end{tabular}

Hasil analisis data minat dan hasil belajar Bahasa Inggris siswa menunjukkan bahwa terdapat pengaruh yang signifikan penggunaan strategi Enjoyable Learning berbantuan media audio visual pada siswa kelas II SD Awal Penerapan Kurikulum 2013 di Kecamatan Buleleng Kabupaten Buleleng Tahun Pelajaran 2018/2019. 
Pertama, strategi Enjoyable Learning berbantuan media audio visual dapat mampu melibataktifkan peran siswa pada proses pembelajaran sesuai dengan fase-fase yang terdapat pada strategi Enjoyable Learning.

Kedua, strategi Enjoyable Learning membuat suasana kelas menjadi menyenangkan. Siswa yang biasanya kurang aktif karena baru pertama kali mendapatkan pelajaran Bahasa Inggris menjadi lebih aktif karena merasa senang dan dirangsang untuk mampu menjawab pertanyaan sederhana berbahasa Inggris. Ketiga, penggunaan media audio visual dalam proses pembelajaran menjadikan siswa senang dan tertarik untuk belajar Bahasa Inggris. Penggunaan media audio visual membantu guru dalam memperjelas penyampaian materi pembelajaran. Siswa lebih tertarik belajar dengan bantuan media audio visual. Media audio visual memberikan pengalaman yang lebih konkret serta mempertinggi daya serap dan daya ingat siswa, sehingga dapat menarik perhatian siswa dalam proses pembelajaran. Pernyataan tersebut didukung oleh pendapat Sadiman (2005:29) menyatakan bahwa media audio visual merupakan bahasa yang umum, yang dapat menarik perhatian, memperjelas sajian ide, mengilustrasikan, dan mudah dimengerti.

\section{Simpulan dan Saran}

Berdasarkan hasil penelitian dan pembahasan dapat disimpulkan bahwa terdapat pengaruh yang signifikan penerapan strategi Enjoyable Learning berbantuan media audio visual pada minat dan hasil belajar Bahasa Inggris dengan siswa kelas II SD Awal Penerapan Kurikulum 2013 di Kecamatan Buleleng Kabupaten Buleleng Tahun Pelajaran 2018/2019. Hal tersebut diperoleh dari perhitungan nilai thitung sebesar 5,34. Untuk mengetahui nilai $t_{\text {tabel }}$ dengan derajat kebebasan $(\mathrm{dk})=44$ taraf signifikansi $(\alpha)=0,05$ diperoleh nilai $t_{\text {tabel }}=2$ 2,023. Dengan membandingkan nilai thitung dan $t_{\text {tabel }}$ diperoleh perbandingan $t_{\text {thitung }}>t_{\text {tabel }}$ ini berarti $\mathrm{H}_{0}$ ditolak dan $\mathrm{H}_{\mathrm{a}}$ diterima. Dari rata-rata $(\tilde{x})$, diketahui $(\tilde{x})$ kelompok eksperimen sebesar 20,86 dan $(\tilde{x})$ kelompok kontrol sebesar 15,18. Hal ini berarti $(\tilde{x})$ eksperimen $>(\tilde{x})$ kelompok kontrol. Dengan demikian strategi strategi Enjoyable Learning berbantuan media audio visual berpengaruh signifikan terhadap hasil belajar Bahasa Inggris pada siswa kelas II SD Awal Penerapan Kurikulum 2013 di Kecamatan Buleleng Kabupaten Buleleng Tahun Pelajaran 2018/2019.

Adapun saran yang dapat diberikan dari proses dan hasil penelitian ini adalah 1) bagi guru, guru hendaknya dapat mengembangkan strategi Enjoyable Learning berbantuan media audio visual untuk meningkatkan minat dan hasil belajar Bahasa Inggris, 2) bagi kepala sekolah, kepala sekolah hendaknya memberikan kesempatan kepada guru untuk mengembangkan potensi yang dimiliki guru melalui FGD. 3) bagi peneliti lain, peneliti lain dapat menggunakan penelitian ini sebagi referensi untuk penelitian sejenis.

\section{Daftar Rujukan}

A, S. (2012). Penilaian Hasil Belajar Dengan Teknik Nontes. Universitas Sanata Dharma.

Agus Suprijono. (2014). Cooperative Learning: Teori dan Aplikasi PAIKEM. Pustaka Pelajar.

Ahmad, Rivai dan Sujana, N. (2011). Media Pembelajaran. Sinar Baru.

Ahmadi, Abu dan Supriyono, W. (2013). Psikologi Belajar. Rineka Cipta.

Depdiknas. (2007). Rencana strategis Departement Pendidikan Nasional 2005 - 2009. Pusat Informasi dan Humas Departemen Pendidikan Nasional.

Layyinah, L. (2017). Menciptakan Pembelajaran Fun Learning Based On Scientific Approach Dalam Pembentukan Karakter. TARBAWY, 4(1), 1-9.

Mahnun, N. (2012). Media Pembelajaran (Kajian terhadap Langkah-langkah Pemilihan Media dan Implementasinya dalam Pembelajaran). An-Nida', 37(1), 27-35.

N, O. (2005). Pentingnya Pendidikan Karakter Dalam Dunia Pendidikan. Nopan Omeri, 9(manager pendidikan), 464-468.

Primasari, R., \& Herlanti, Y. (2015). Penggunaan Media Pembelajaran Di Madrasah Aliah Negeri Se-Jakarta Selatan. Edusains, 6(1), 67-72. https://doi.org/10.15408/es.v6i1.1101

Susarno, L. . (2010). Strategi penyampaian bahan ajar melalui pemanfaatan metode dan media dalam proses pembelajaran. Jurnal Teknologi Pendidikan, 10(1), 1-7. 